Salmonelloza u dzieci hospitalizowanych w Szpitalu Pediatrycznym w Bielsku - Białej w latach 2014 - 2015

\title{
Salmonellosis among children hospitalized in Pediatric Hospital in Bielsko-Biała, Poland, in the years 2014-2015
}

\section{Wioletta Pollok-Waksmańska, Krystyna Słowiaczek, Danuta Wijas}

Wydział Nauk o Zdrowiu, Katedra Zdrowia Publicznego, Akademia Techniczno-Humanistyczna w Bielsku-Białej

\begin{abstract}
Zakażenia wywoływane pałeczkami z rodzaju Salmonella są poważną przyczyną nieżytu żołądkowo-jelitowego u dzieci. Prewencja poprzez odpowiednią higienę, w celu zminimalizowania ryzyka potencjalnej ekspozycji, jest kluczowa w zmniejszeniu liczby zachorowań. Celem pracy była analiza częstości występowania salmonellozy u dzieci w Szpitalu Pediatrycznym w Bielsku-Białej $\mathrm{z}$ uwzględnieniem serotypów pałeczek Salmonella, objawów przy przyjęciu oraz zmiany masy ciała dzieci podezas pobytu w szpitalu.
\end{abstract}

Słowa kluczowe: Salmonelloza, Salmonella Enteritidis, epidemiologia

\begin{abstract}
Introduction: Salmonella is a serious cause of gastroenteritis in children. Prevention through proper hygiene to minimize potential exposure is a key factor decreasing the number of morbidity. The aim of this study was the analysis of Salmonellosis incidence rate among children hospitalized in Pediatric Hospital in Bielsko-Biała, Poland, in the years 2014-2015 having regard to Salmonella's serotype, symptoms at admission to hospital and changes of body weight during hospital stay.

Methods: The study was conducted on 79 children with Salmonellosis treated in years 2014-2015 in Pediatric Hospital in Bielsko-Biała, Poland. It was based on retrospective analysis of data from children's medical history.

Results: In all age groups the most common serotype was Salmonella Entertidis. Analysis of children's clinical symptoms at admission to hospital showed that all children, both male and female, had abdominal pains before defecation. The major symptoms included also diarrhea with blood and fever. Among half of observed group emesis were observed.
\end{abstract}


The analysis of body weight at the hospital admission and discharge demonstrated that in majority of children the body weight increased during their stay in the hospital - the weight gain occurred in $68,8 \%$ of male and in $48,4 \%$ of female children.

Conclusions: The cases of Salmonella appeared comparatively often in children at the age of 0-2 years old and 3-5 years old. The most commonly isolated serotype of Salmonella was Salmonella Entertidis. In all age groups the most common symptoms were abdominal pain before defecation and diarrhea with blood. Due to high diarrhea prevalence it is advisable to introduce the education directed both to children and parents.

Keywords: Salmonellosis, Salmonella Enteritidis, epidemiology

\section{WSTĘP}

Choroby biegunkowe są jedną z głównych przyczyn zgonów dzieci (10). Szacuje się, że biegunka jest drugą co do częstości, zaraz po zakażeniach układu oddechowego, przyczyną umieralności wśród dzieci (12). Epizod trwający mniej niż 2 tygodnie klasyfikujemy jako biegunkę ostrą, a gdy trwa ona 2 tygodnie lub dłużej, jako biegunkę przewlekłą (22). Najczęstszym czynnikiem etiologicznym ostrej biegunki u dzieci jest zakażenie wirusowe (ok. 70\% zachorowań), z występowaniem rotawirusów i norowirusów, rzadziej przyczyną są zakażenia bakteryjne, m.in. Salmonella, Shigella, Campylobacter, enteropatogenne szczepy Escherichia coli (4). Pałeczki Salmonella są przyczyną około 90 milionów zakażeń i 155.000 zgonów rocznie, a średnia zachorowalność wynosi 1,14 zakażeń/100 osób rocznie. Statystyki są znacznie wyższe w Azji, gdzie zapadalność wynosi 4,72/100 osób rocznie (2).

Gram - ujemne pałeczki Salmonella należą do rodziny Enterobacteriaceae i obecnie dzieli się je na dwa gatunki: S. enterica i S. bongori $(6,7)$. Salmonella enterica dzieli się na sześć podgatunków (subspecies): enterica (I), salamae (II), arizonae (III a), diarizonae (III b), houtenae (IV), indica (VI), z czego Salmonella enterica subsp. enterica (I) odpowiada za około 99\% infekcji u ludzi $(2,6)$. Dodatkowo rodzaj Salmonella został podzielony na wiele serotypów (serowarów) (19). Serotypy najczęściej związane z zachorowaniem u ludzi zamieszkałych w krajach należących do w Unii Europejskiej to $S$. Enteritidis i $S$. Typhimurium (7).

Najczęstszym powodem zakażenia pałeczkami Salmonella jest skażona żywność (drób, jajka, produkty mleczne), u dzieci zdarzają się także przypadki zarażenia drogą fekalno-oralną. Obróbka termiczna produktów żywnościowych oraz odpowiednie mycie rąk są fundamentalne w unikaniu zakażeń $(16,18)$.

Wyróżnia się cztery formy kliniczne zakażenia pałeczkami Salmonella. Najczęściej występującą postacią jest nieżyt żołądkowo-jelitowy. Mogą powodować one również posocznice, dur brzuszny ( $S$. Typhi) i dury rzekome ( $S$. Paratyphi A, B i C) oraz bezobjawową kolonizację (rezerwuarem bakterii jest wtedy woreczek żółciowy) $(8,14,16)$. Okres inkubacji wynosi 6-72 godzin (11). Objawami zapalenia jelit są nudności, wymioty, wodnista biegunka, często również gorączka, dreszcze, bóle brzucha, mięśni i głowy. Podczas ostrej fazy zakażenia zajęta jest błona śluzowa jelita cienkiego i okrężnicy. Objawy utrzymują 
się 2-7 dni. Pałeczki Salmonella są wydalane z kałem po infekcji przez około 5 tygodni. Bakteriemia występuje u 5-10\% zakażonych osób, a niektóre z nich mogą rozwinąć infekcję ogniskową, taką jak zapalenie opon mózgowych oraz zakażenie kości i stawów. $(2,14)$.

Celem pracy była ocena częstości występowania zakażeń pałeczkami Salmonella, z uwzględnieniem serotypów, u dzieci w grupie wiekowej od 0 - 16 lat zgłaszających się z ostrą biegunką do Szpitala Pediatrycznego w Bielsku-Białej.

\section{MATERIAŁ I METODY}

Analizą objęto pacjentów hospitalizowanych od 1.01.2014 r. do 31.12.2015 r. w Szpitalu Pediatrycznym w Bielsku - Białej. Badane dzieci to mieszkańcy terenu Podbeskidzia, w przedziale wiekowym od 0 - 16 lat. Na przeprowadzone badania uzyskano zgodę Dyrekcji szpitala. Oceniano częstość występowania u dzieci objawów klinicznych przy przyjęciu do szpitala, rodzaj wyhodowanych drobnoustrojów z posiewu kału oraz stosunek zmian masy ciała przy przyjęciu i przy wypisie dziecka.

Metodą badawczą była retrospektywna analiza zebranych danych z historii chorób dzieci z zakażeniem pałeczkami z rodzaju Salmonella. Dane, które pozyskano to: wiek, płeć, liczebność, rodzaj wystąpienia objawów klinicznych przy przyjęciu do szpitala. Wszystkim dzieciom pobierano krew, mocz i kał na badania. U dzieci od $0-2$ lat kał wysyłano do laboratorium Stacji Sanitarno-Epidemiologicznej. Pobierano 3 próbki na posiew, a u dzieci powyżej 2 lat posiew kału wykonywano w przyszpitalnym laboratorium i pobierano dwie próbki kału. Każde dziecko miało wykonane przy przyjęciu lub następnego dnia badanie USG jamy brzusznej. Wszystkie dzieci były nawadniane pozajelitowo. Otrzymywały dożylnie odpowiednią ilość płynów z uzupełnieniem 8,4\% NaHCO3 lub 15\% KCL w zależności od niedoborów elektrolitowych.

Analizą objęto 79 dzieci. W badanej grupie było 48 chłopców i 31 dziewcząt z zakażeniem pałeczkami Salmonella. W grupie wiekowej od 0 - 2 lat było 18 (37,5\%) chłopców i $8(25,8 \%)$ dziewcząt, w wieku od 3 - 5 lat było 16 (33,3\%) chłopców i 12 (38,7\%) dziewcząt, w wieku od 6 - 10 lat było $9(18,8 \%)$ chłopców i $8(25,8 \%)$ dziewcząt, natomiast w wieku od 11 - 16 lat było 5 chłopców (10,4\%) i 3 dziewcząt (9,7\%): (Tabela I).

Tabela I. Liczebność badanej grupy w 2014 i 2015 roku z podziałem według płci i wieku.

\begin{tabular}{|c|c|c|c|c|c|c|c|c|c|c|}
\hline \multirow{3}{*}{ Płeć } & \multicolumn{9}{|c|}{ Przedział wiekowy/ wiek w latach } & \multicolumn{3}{c|}{ Ogółem } \\
\cline { 2 - 13 } & \multicolumn{2}{|c|}{$0-2$ lat } & \multicolumn{2}{|c|}{$3-5$ lat } & \multicolumn{2}{|c|}{$6-10$ lat } & \multicolumn{2}{|c|}{$11-16$ lat } & \multicolumn{2}{c|}{} \\
\cline { 2 - 12 } & $\mathrm{n}$ & $\%$ & $\mathrm{n}$ & $\%$ & $\mathrm{n}$ & $\%$ & $\mathrm{n}$ & $\%$ & $\mathrm{n}$ & $\%$ \\
\hline Chłopiec & 18 & $37,5 \%$ & 16 & $33,3 \%$ & 9 & $18,8 \%$ & 5 & $10,4 \%$ & 48 & $100 \%$ \\
\hline Dziewczynka & 8 & $25,8 \%$ & 12 & $38,7 \%$ & 8 & $25,8 \%$ & 3 & $9,7 \%$ & 31 & $100 \%$ \\
\hline
\end{tabular}

$\mathrm{n}$ - liczba dzieci, \% - odsetek z grupy chłopców lub dziewcząt

\section{WYNIKI}

We wszystkich grupach wiekowych najczęściej występującym serotypem pałeczek Salmonella była $S$. Enteritidis. W grupie dzieci od $0-2$ lat kolejne miejsca pod względem 
częstości występowania zajęły serotypy: $S$. Mbandaka, $S$. Infantis, $S$. Paratyphi B oraz $S$. Enterica podgat. 3, w grupie wiekowej 3 - 5 lat były to Salmonella sp., S. Typhimurium, $S$. Infantis i $S$. Mbandaka. W grupie wiekowej 6-10 lat występowały serotypy Salmonella $s p$., $S$. Typhimurium oraz $S$. Mbandaka, a w grupie dzieci $11-16$ lat oprócz serotypu $S$. Enteritidis wystąpił jeden przypadek $S$. Typhimurium (Tabela II).

Tabela II. Wyhodowany serotyp pałeczek Salmonella z posiewu kału w badanej grupie dzieci z podziałem według płci i wieku.

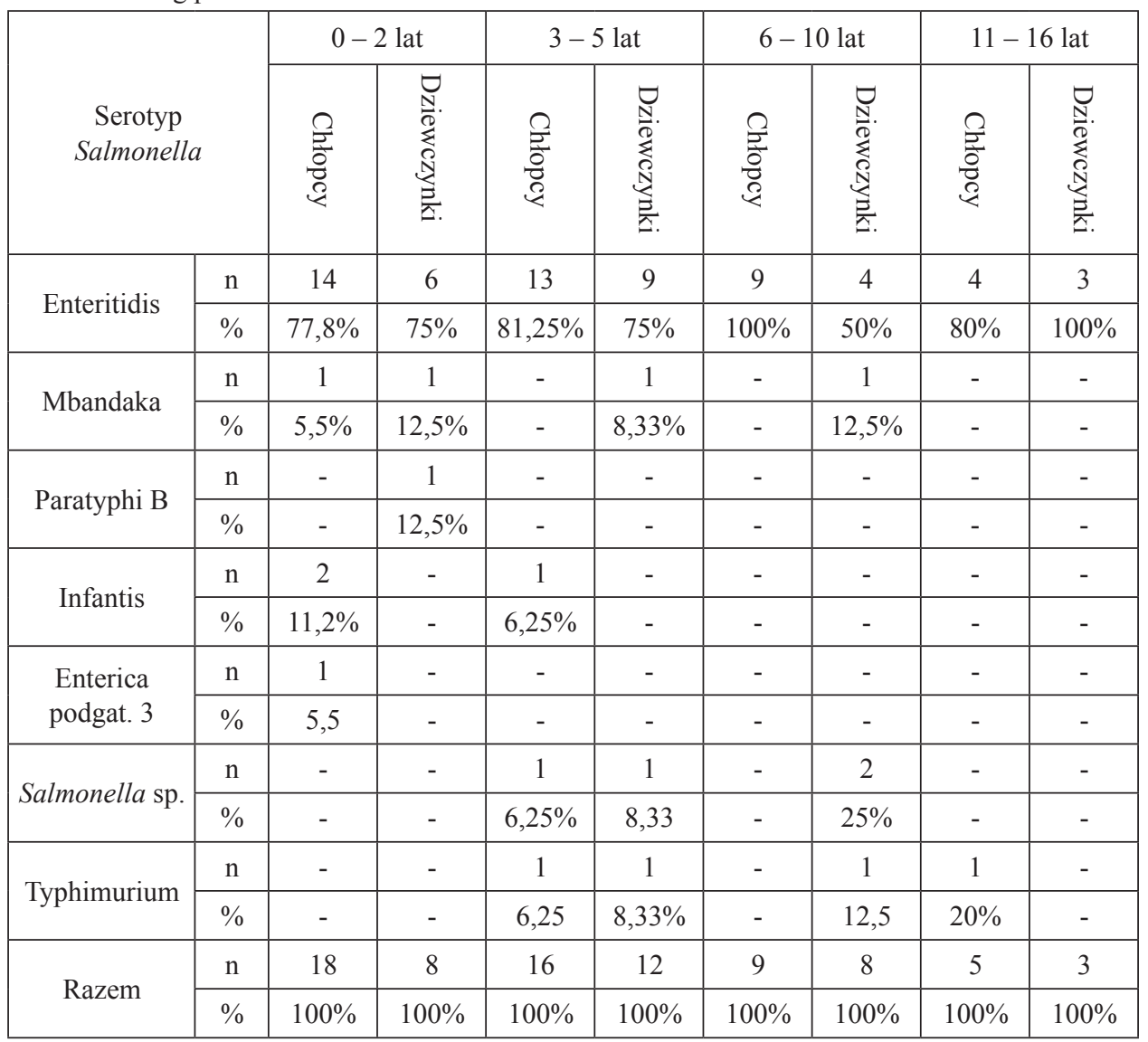

n - liczba dzieci, \% - odsetek z grupy chłopców lub dziewcząt

Przeprowadzona analiza objawów klinicznych występujących u dzieci przy przyjęciu do szpitala wykazała, że u wszystkich dzieci, zarówno chłopców jak i dziewcząt występowały bóle brzucha przed oddaniem stolca, do głównych objawów należała również biegunka z krwią oraz gorączka. U około połowy dzieci zaobserwowano wymioty - wystąpiły one u 51,6\% dziewcząt i u 43,8\% chłopców (Tabela III).

Przeprowadzona analiza masy ciała przy przyjęciu i przy wypisie wykazała, że u jednej z dziewczynek masa ciała była bez zmian, a u połowy grupy nastąpił przyrost masy ciała. W grupie chłopców u większości wystąpił przyrost masy ciała (68\%) (Tabela IV). 
Tabela III. Objawy występujące u dzieci przyjętych do Szpitala Pediatrycznego w Bielsku-Białej w latach 2014 i 2015.

\begin{tabular}{|c|c|c|c|c|c|c|c|c|c|}
\hline & & $0-$ & lat & $3-$ & lat & $6-$ & lat & $11-$ & 6 lat \\
\hline $\begin{array}{l}\text { Występowan } \\
\text { objawów pr } \\
\text { przyjęciu }\end{array}$ & & $\frac{\Omega}{0}$ & 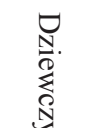 & $\begin{array}{l}\Omega \\
\frac{0}{0}\end{array}$ & 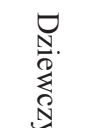 & $\frac{\Omega}{0}$ & 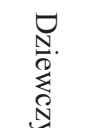 & $\frac{\beta}{\frac{0}{0}}$ & 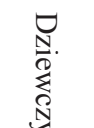 \\
\hline Ból brzucha & $\mathrm{n}$ & 18 & 8 & 16 & 17 & 9 & 8 & 5 & 3 \\
\hline stolca & $\%$ & $100 \%$ & $100 \%$ & $100 \%$ & $100 \%$ & $100 \%$ & $100 \%$ & $100 \%$ & $100 \%$ \\
\hline Biegunka z & $\mathrm{n}$ & 17 & 7 & 15 & 17 & 9 & 7 & 5 & 3 \\
\hline & $\%$ & $94,4 \%$ & $87,5 \%$ & $93,8 \%$ & $100 \%$ & $100 \%$ & $87,5 \%$ & $100 \%$ & $100 \%$ \\
\hline & $\mathrm{n}$ & 16 & 8 & 15 & 16 & 9 & 8 & 5 & 3 \\
\hline & $\%$ & $88,9 \%$ & $100 \%$ & $93,8 \%$ & $94,1 \%$ & $100 \%$ & $100 \%$ & $100 \%$ & $100 \%$ \\
\hline & $\mathrm{n}$ & 5 & 5 & 8 & 6 & 6 & 4 & 2 & 1 \\
\hline & $\%$ & $27,8 \%$ & $62,5 \%$ & $50 \%$ & $35,3 \%$ & $75 \%$ & $44,4 \%$ & $40 \%$ & $33,3 \%$ \\
\hline
\end{tabular}

n- liczba dzieci u których wystąpiły objawy, \% - odsetek dzieci z objawami

Tabela IV. Zmiana masy ciała przy wypisie w stosunku do masy ciała przy przyjęciu w analizowanej grupie z podziałem według płci i wieku dzieci.

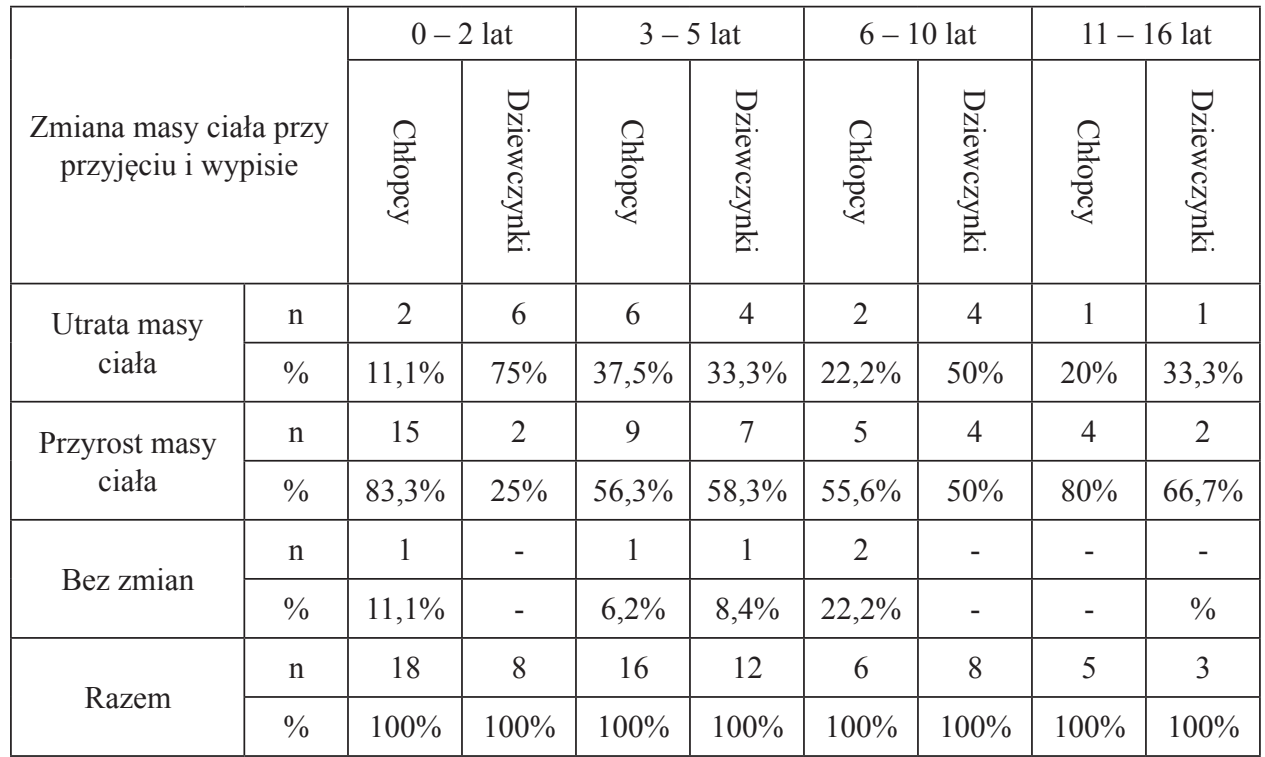

n - liczba dzieci, \% - odsetek z grupy chłopców 


\section{DYSKUSJA}

Pałeczki z rodzaju Salmonella są częstym patogenem ludzi, a większość pacjentów których dotyczy zakażenie, to dzieci poniżej 5 roku życia (2). Źródłem zakażeń są głównie produkty pochodzenia zwierzęcego, szczególnie jaja i drób (20). Częściej chorują osoby z niedokwasotą żołądka, po niedawnej antybiotykoterapii, leczeniu immunosupresyjnym, dzieci oraz osoby starsze (3).

W latach 2007 - 2013 przeprowadzono retrospektywne badania zakażenia pałeczkami Salmonella w wybranych powiatach województwa kujawsko - pomorskiego. Najczęściej izolowanym serotypem z 1452 próbek kału była Salmonella Enteritidis - 1071 przypadków tj. 74,5\% wszystkich izolacji. W dalszej kolejności znalazły się $S$. Typhimurium - 101 przypadków $(7,0 \%), S$. Infantis - 55 przypadków (3,8\%), S. Virchow - 46 przypadków $(3,2 \%), S$. Mbandaka - 27 przypadków $(1,9 \%)$ oraz $S$. Hadar - 24 przypadki $(1,7 \%)$. Najwięcej izolacji pochodziło od pacjentów z grupy wiekowej od 0 - 4 lat (32\%) (23).

W latach 2002 do 2012 przeprowadzono analizę sytuacji epidemiologicznej salmonelloz odzwierzęcych zarejestrowanych w Powiatowej Stacji Sanitarno - Epidemiologicznej w Szczecinie. Spośród wszystkich zgłoszonych 1234 zachorowań, 762 (61,8\%) dotyczyło dzieci do 14. roku życia. Najczęstszym rejestrowanym serotypem była Salmonella Enteritidis. Udział zachorowań tym typem Salmonelli wyniósł 84,85\%. Kolejne miejsca zajęły $S$. Typhimurium, Infantis, Hadar, Mbandaka i Virchow (13).

W 2014 roku została przeprowadzona ocena sytuacji epidemiologicznej salmonellozy w Polsce. Ocenę przeprowadzono na podstawie danych z biuletynu „Choroby zakaźne i zatrucia w Polsce w 2014”. W 2014 roku w Polsce zarejestrowano 8392 zachorowania na salmonellozy odzwierzęce, w tym 8197 przypadków salmonellozy jelitowej i 195 pozajelitowej. Z 5 serotypów najczęściej powodującym zachorowania we wszystkich województwach była $S$. Enteritidis. Ten typ serologiczny spowodował $76 \%$ ogólnego zachorowania na salmonellozę. $S$. Typhimurium była na drugiej pozycji na liście wykrytych serotypów. Najczęściej na salmonellozy chorowały dzieci w wieku poniżej 5 roku życia (17). W badaniach własnych najczęściej izolowanym serotypem pałeczek Salmonella u dzieci była $S$. Entertidis. Grupą wiekową, w której najczęściej rozpoznawano salmonellozy były dzieci do 5. roku życia (dziewczynki poniżej 5 lat stanowiły $64,5 \%$ chorych dziewczynek, a chłopcy $70,8 \%$ ).

Badania wskazują, że zakażenia pałeczkami Salmonella występują częściej u dzieci płci męskiej $(1,15)$. Według badań przeprowadzonych w Stanach Zjednoczonych w latach 1968 - 2000 częściej rozpoznaje się salmonellozę u chłopców niż u dziewczynek, ale w dorosłym wieku częściej występuje ona u kobiet (15). W badaniach własnych przeprowadzono analizę z podziałem według płci i zaobserwowano większą liczbę dzieci płci męskiej niż żeńskiej przyjmowanych do szpitala z zakażeniem pałeczkami Salmonella. W latach 2014 - 2015 liczba przyjętych chłopców wynosiła 48, a dziewcząt 31.

W 2017 roku przedstawiono przypadek czternastoletniego chłopca, u którego przebieg zakażenia $S$. Enteritidis początkowo imitował objawy neuroinfekcji. W dniu poprzedzającym przyjęcie chłopiec gorączkował, zgłaszał światłowstręt i ból głowy, który nasilał się przy pionizacji. W dniu przyjęcia do Kliniki pojawiła się wodnista biegunka bez patologicznych domieszek. Potwierdzenie zakażenia nastąpiło na podstawie posiewu kału (21). We włoskich badaniach przeprowadzonych w 2003 roku wśród dzieci, które trafiły do szpitala w Palermo 
z ostrym nieżytem żołądkowo-jelitowym, u prawie wszystkich pacjentów występowała biegunka oraz gorączka, u 55\% pojawił się też jeden lub więcej epizod wymiotów (18). W badaniach własnych u wszystkich dzieci przy przyjęciu do szpitala występowały bóle brzucha przed oddaniem stolca, u większości objawami była również biegunka z krwią i gorączka. U około połowy dzieci (51,6\% dziewcząt i 43,8\% chłopców) wystąpiły wymioty.

$\mathrm{W}$ badaniach własnych u większości pacjentów zaobserwowano przyrost masy ciała przy wypisie w porównaniu do masy ciała przy przyjęciu (przyrost masy ciała wystąpił u 68,8\% dzieci płci męskiej i 48,4\% dzieci płci żeńskiej). Inni autorzy w swoich badaniach nie przedstawiają informacji na temat zmian masy ciała podczas zakażeń.

Biegunki wywołane pałeczkami z rodzaju Salmonella spowodowane są nieprzestrzeganiem zasad higieny podczas przygotowywania posiłków i zbyt rzadkim myciem rąk. Nieodpowiednia obróbka termiczna oraz przechowywanie potraw w temperaturze pokojowej powoduje namnażanie się i rozprzestrzenianie drobnoustrojów w zbiorowiskach ludzkich (18). Wskazane jest więc prowadzenie edukacji w tym zakresie skierowanej zarówno do dzieci jak i rodziców.

\section{PODSUMOWANIE}

1. Porównywalnie często zakażenie pałeczkami Salmonella występowało u dzieci w grupach wieku: $0-2$ oraz $3-5$ lat.

2. Najczęściej izolowanym wśród dzieci serotypem pałeczek Salmonella była Salmonella Enteritidis.

3. We wszystkich grupach wiekowych dominującym objawem były bóle brzucha przed oddaniem stolca oraz biegunka z krwią.

4. Ze względu na częste występowanie biegunek wskazane jest prowadzenie edukacji skierowanej zarówno do dzieci jak i do rodziców.

\section{PIŚMIENNICTWO}

1. Aiat Melloul A, Hassani L. Salmonella infection in children from the wastewater- spreading zone of Marrakesh city (Morocco). J Appl Microbiol 1999; 87, 4: 536-9.

2. Chen HM, Wang Y, Su LH, Chiu CH. Nontyphoid Salmonella Infection: Microbiology, Clinical Features, and Antimicrobial Therapy. Pediatr Neonatol 2013; 54, 3: 147-52.

3. Crum-Cianflone NF. Salmonellosis and the GI Tract: More than Just Peanut Butter. Curr Gastroenterol Rep 2008; 10, 4: 424-31.

4. Czerwionka-Szaflarska $M$, Adamska I. Ostra biegunka u dzieci- najnowsze wytyczne. Forum Med Rodz 2009; 3, 6: 431-8.

5. Elliott EJ. Acute gastroenteritis in children. BMJ 2007; 6, 334: 35-40.

6. Eng SK, Pusparajah P, Ab Mutalib NS, Ser HL, Chan KG, Lee LH. Salmonella: A review on pathogenesis, epidemiology and antibiotic resistance. Frontiers in Life Science $2015 ; 8,3: 284-93$.

7. European Union Summary Report on Trends and Sources of Zoonoses, Zoonotic Agents and Food-borne Outbreaks in 2010. EFSA Journal. 2012; 10, 3: 2597.

8. Gal-Mor O, Boyle EC, Grassl GA. Same species, different diseases: how and why typhoidal and non-typhoidal Salmonella enterica serovars differ. Front Microbiol 2014; 4, 5: 391 . 
9. Guarino A, Ashkenazi S, Gendrel D. Evidence-Based Guidelines for Management of Gastroenteritis in Children in Europe. JPGN 2014; 59, 1: 132-52.

10. Guerrant RL, Huhhes JM, Lima NI, Crane J. Diarrhea in Developed and Developing Countries: Magnitude, Special Settings, and Etiologie. Rev Infect Dis 1990; 12, 1: 41-50.

11. Hohmann EL. Nontyphoidal Salmonellosis. Clin Infect Dis 2001; 15, 32, 2: 263-9.

12. Kelly P. Diarrhoeal disease. Clin Med 2011; 11, 5: 488-91.

13. Król-Pakulska E, Szlempo N, Pakulski C. Sytuacja epidemiologiczna salmoneloz odzwierzęcych w Szczecinie w latach 2002-2012. Pol Prz Nauk Zdr 2013; 1, 31: 32-7.

14. Murray PR, Rosenthal KS. Medical Microbiology. Sixth edition. Elsevier, 2009: 299301.

15. Reller ME, Tauxe RV, Kalish LA, Molbak K. Excess salmonellosis in women in the United States: 1968-2000. Epidemiol Infect 2008: 138, 8: 1109-17.

16. Rożkiewicz D, Ołdak E. Bakteryjne zakażenie przewodu pokarmowego u dzieci. Gastroneterol Prakt 2014; 27: 11 - 3.

17. Sadkowska-Todys M, Czarkowski, MP. Salmonellozy w Polsce w 2014 roku. Prz Epidemiol 2016; 70: 358-66.

18. Saporito L, Colomba C, Scarlata F, Vrcchi V, Mammina C, Titone L. Clinical and microbiological features of Salmonella gastroenteritis in children. Infez Med 2007; 15: 24-9.

19. Su LH, Chiu CH. Salmonella: Clinical Importance and Evolution of Nomenclature. Chang Gung Med J 2007; 30: 210-9.

20. Suh DK, Song JC. Analysis of Salmonella enterica serotype Enteritidis isolated from human and chickens by repetitive sequence-PCR fingerprinting, antibiotic resistance and plasmid profiles. J Vet Sci 2006; 7: 37-41.

21. Szewczyk M, Pokorska - Śpiewak M, Szczepaniak K. Zakażenie Salmonella enteritidis imitujące neuroinfekcję u czternastoletniego pacjenta - opis przypadku. Pediatr Pol 2017; 92, 2: 210-3.

22. World Health Organisation. The management and prevention of diarrhoea: practical guidelines. $3^{\text {rd }}$ ed. 1993. https://apps.who.int/iris/handle/10665/37036

23. Zuziakowski M, Kasprzak, J. Klawe J. Analiza retrospektywna zakażeń pałeczkami Salmonella w latach 2007 - 2013 w wybranych powiatach województwa kujawsko pomorskiego. Probl Hig Epidemiol 2014; 95: 616-23.

Otrzymano: 18 XII $2018 \mathrm{r}$.

Adres Autora: 43-300 Bielsko-Biała, ul. Willowa 2, Wydział Nauk o Zdrowiu, Akademia Techniczno-Humanistyczna 